\title{
Sediment, Nutrient, and Bacterial Runoff from Biosolids and Mineral Fertilizer Applied to a Mixed Cool- and Native Warm-Season Grassland in the Ozark Mountains
}

\author{
Cody B. Wallace, ${ }^{1}$ Michael G. Burton, ${ }^{2}$ Steven G. Hefner, ${ }^{3}$ and Thomas A. DeWitt ${ }^{2}$ \\ ${ }^{1}$ Missouri State University, P.O. Box 291, Isabella, MO 65676, USA \\ ${ }^{2}$ William H. Darr School of Agriculture, Missouri State University, 901 S. National Avenue, Springfield, MO 65897, USA \\ ${ }^{3}$ Missouri State Staff, USDA Natural Resources Conservation Service State Office, Parkade Center, Suite 250, \\ 601 Business Loop 70 West, Columbia, MO 65203-2546, USA \\ Correspondence should be addressed to Michael G. Burton; mikeburton@missouristate.edu
}

Received 30 July 2013; Accepted 28 November 2013; Published 29 January 2014

Academic Editor: Silvana Irene Torri

Copyright (C) 2014 Cody B. Wallace et al. This is an open access article distributed under the Creative Commons Attribution License, which permits unrestricted use, distribution, and reproduction in any medium, provided the original work is properly cited.

Rainfall simulations were conducted within mixed (cool- and native warm-season) grasslands in the sloping, rocky soils typical of the Ozark Mountains region to estimate nutrient and bacteria levels in runoff from biosolids and mineral fertilizer (MF). The ability of narrow (1 m) vegetated filter strips (VFS) to reduce losses was evaluated. Experiment 1 included an untreated control (C); $37 \mathrm{~kg}$ plant available nitrogen (PAN) ha ${ }^{-1}$ from biosolids applied to the upslope half of the plot with the downslope half serving as a VFS (LBF); $74 \mathrm{~kg} \mathrm{PAN} \mathrm{ha}{ }^{-1}$ from biosolids, with VFS (HBF); and a uniform biosolids application at the lower rate and no VFS (LBU). Experiment 2 examined runoff from MF applied at $89 \mathrm{~kg}$ ammoniacal nitrogen $\left(\mathrm{NH}_{4}-\mathrm{N}\right) \mathrm{ha}^{-1}$ and $147 \mathrm{~kg}$ phosphorous $(\mathrm{P})$ ha ${ }^{-1}$ over the whole plot (MFW) or only on the upslope half (with VFS) (MFF). No significant differences were detected among mean fecal coliform levels despite large differences in magnitude. Losses of $\mathrm{NH}_{4}-\mathrm{N}$ and $\mathrm{P}$ were greater for LBU than for LBF. Although only marginally significant $(P=0.058)$, total phosphorous contained in runoff was nearly three times higher in MFW than in MFF. Results of this study suggest that even a small VFS can potentially reduce nutrient levels in runoff.

\section{Introduction}

An estimated 226,800 dry tonnes of biosolids are produced each year in Missouri where $60 \%$ of the sludge is incinerated and $30 \%$ is applied to agricultural land [1]. However, nearly all biosolids produced by the city of Springfield, Missouri, are applied to agricultural land. Many benefits and concerns associated with biosolids application to agricultural lands were recently reviewed by Torri et al. [2] and Lu et al. [3]. Among the benefits, biosolids provide recycled nutrients to soils and can serve as an alternative or a substitute to costly mineral fertilizers (MF). In addition to providing nutrients, biosolids provide organic matter to soil $[4,5]$, increase infiltration [6], potentially improve soil quality $[5,7$, $8]$, and increase agronomic productivity [5, 7, 9-12]. Using biosolids as a substitute for MF also helps reduce energy use which would have been associated with production and transportation of MF.
A considerable body of research has confirmed the potential for losses of nutrients such as nitrogen $(\mathrm{N})$ and phosphorus (P) from agricultural fertilizers applied to fields [13-17] while less data are available for hay and grazing lands $[18,19]$. Nitrogen levels are often a limiting factor for application; however, in a 2003 national biosolids survey, Shober and Sims [20] determined that about one half of the states in the USA have established regulations, guidelines, or legislation that can be used to limit land application of biosolids based on a measure of soil $\mathrm{P}$ or biosolids $\mathrm{P}$. Therefore, data for both $\mathrm{N}$ and $\mathrm{P}$ could be required to conform to regulations. Federal (USA) and Missouri state regulations require that biosolids application rates do not exceed plant available nitrogen (PAN) levels that can be immobilized by the crop [21, 22]. Regulation of land application of manures or biosolids on the basis of $\mathrm{P}$ is not yet required in Missouri. Sediment and fecal bacteria are other pollutants that contribute to the degradation of water sources. Biosolids 
and animal manures may increase sediment loads and can contain high amounts of coliform bacteria that are often carried in surface runoff from agricultural fields $[23,24]$.

Management practices that can potentially influence nonpoint source pollution levels and water quality include a shift in fertilizer time of application and the use of vegetated filter strips (VFS) to reduce contaminant content. In central and southern Missouri nearly two-thirds of cool-season forage production occurs in spring. Consequently, some producers have shifted fertilizer, manure, or biosolids application to late summer in an effort to increase autumn production either for hay harvest or winter grazing (M. Green and M. Kennedy, pers. comm.). VFS have proven effective in reducing sediment [23-26] and nutrient levels [27-29], but the magnitude of the reduction in nutrient loads often depends on the nutrient and its form [25]. For example, Daniels and Gilliam [25] observed that runoff collected at field edges and various locations in vegetated buffers showed that VFS reduced total phosphorus (TP) load by $50 \%$, but as much as $80 \%$ of the soluble $\mathrm{PO}_{4}$-P passed through filters. VFS are not highly efficient in trapping fecal bacteria from surface runoff; several studies have shown significant yet still unacceptable reductions in fecal coliform counts [23, 27, 30,31].

The following two experiments were conducted to provide additional data on fertilization management and VFS efficacy on grassland typical of the Ozarks region (i.e., sloping, rocky soils). The biosolids experiment evaluated and compared sediment, nutrient, and bacteria levels found in runoff from biosolids applications with or without a VFS. Biosolids were applied at PAN levels typically applied to native warm-season grasses. The mineral fertilizer experiment investigated the efficacy of a narrow VFS in reducing sediment, nutrient, and bacteria pollutant loads.

\section{Materials and Methods}

2.1. Site Conditions and Rainfall Simulation. Rainfall simulations were conducted from August 2009 to October 2009 on field plots with a Nixa very gravelly silt loam (loamy-skeletal, siliceous, active, mesic Glossic Fragiudults) in Lawrence County, Missouri. Vegetation in plots consisted of a mixture of cool- (especially Lolium arundinaceum (Schreb.) Darbysh.) and native warm-season grasses (e.g., Sorghastrum nutans (L.) Nash and Andropogon gerardii Vitman). The study site has been hayed, rather than grazed, since 2006 .

Surface runoff plots $1.50 \times 2.00 \mathrm{~m}$ (long axis oriented downslope) had metal borders $5 \mathrm{~cm}$ above and below ground level in order to isolate runoff. Each experiment was conducted with four replicates. The plots were mowed to a height of $10 \mathrm{~cm} 7$ to 10 days prior to rainfall simulations and had similar vegetative cover conditions. A full replication of each experiment was carried out on each of 4 days (Table 1). Plots were selected for replications to optimize uniformity of slope. Slopes of plots used in the experiment ranged from 3 to $6 \%$.

Portable rainfall simulators [32] fitted with plastic tarps to provide a wind screen were used to apply rainfall to plots (3 rainfall simulators were employed twice each day). The rainfall simulators were equipped with a single Spraying Systems
TABLE 1: Mean volumetric soil moisture, percent vegetative cover, and mean runoff volume from each of the four blocks used in this study.

\begin{tabular}{lccc}
\hline Date & $\begin{array}{c}\text { \% Volumetric } \\
\text { soil moisture }\end{array}$ & $\begin{array}{c}\text { \% Vegetative } \\
\text { cover }\end{array}$ & $\begin{array}{c}\text { Mean runoff } \\
\text { volume (L) }\end{array}$ \\
\hline Aug. 20, 2009 & 39.1 & 84.4 & 57.1 \\
Aug. 27, 2009 & 19.6 & 93.8 & 25.4 \\
Sep. 03, 2009 & 24.3 & 88.8 & 14.6 \\
Oct. 13, 2009 & 46.7 & 97.2 & 80.2 \\
\hline
\end{tabular}

Fulljet HH50WSQ (brand name is included for specificity, not as an official endorsement of a particular product) nozzle at a height of $3 \mathrm{~m}$, were centered over plots, and had an operating nozzle pressure of $28 \mathrm{kPa}$ to yield a rainfall intensity of $70 \mathrm{~mm} \mathrm{~h}^{-1}$ [32] with droplet size and velocity similar to natural rainfall. Rainfall occurring at this intensity for $0.5 \mathrm{~h}$ duration has an approximate probability of occurring once every two years in southwest Missouri and imitated an imprudent scenario in which fertilizer application occurred immediately before a heavy thunderstorm. Deionized water $(>50 \mathrm{k} \mathrm{Ohm}$ resistance), provided by cation and anion exchange columns, was used as the water source for the simulators. Additional filtration was provided by an inline filter located on each simulator upstream of the pressure regulator to prevent foreign particles from clogging the regulator and nozzle. The rainfall intensity was applied until $30 \mathrm{~min}$ of runoff was collected. Surface runoff was collected in metal gutters at the downslope edge of each plot and pumped from the collector bucket to a $190 \mathrm{~L}$ plastic barrel, which was lined with a clean plastic liner. During simulated rainfall, runoff collection gutters were covered to exclude water that had not fallen on the plot surface first. Total surface runoff was then measured, and the bulk solution was agitated so that a subsample $(1900 \mathrm{~mL})$ could be collected for laboratory analyses. Tubing and pumps used in sample collection were cleaned before each use by flushing with a $0.5 \%$ sodium hypochlorite solution for two minutes followed by thoroughly rinsing with deionized water.

Samples were labeled with a randomly assigned reference number, stored in ice water, and delivered to the Southwest Water Treatment Plant in Springfield, Missouri, within $7 \mathrm{~h}$ of collection for stabilization and analyses. Analyses were completed for total suspended solids (TSS), total Kjeldahl nitrogen (TKN), dissolved total Kjeldahl nitrogen (DTKN), $\mathrm{NH}_{4}-\mathrm{N}$, dissolved ammoniacal nitrogen $\left(\mathrm{DNH}_{4}-\mathrm{N}\right)$, nitrate nitrogen $\left(\mathrm{NO}_{3}-\mathrm{N}\right)$, TP, dissolved phosphorus (DP), and fecal coliform colony-forming units (CFUs) levels. TSS, $\mathrm{NH}_{4}-\mathrm{N}$, and CFUs were determined according to standard biosolids protocols [33]. TKN was determined by semiautomated colorimetry [34] and TP was determined by automated colorimetry [35]. $\mathrm{NO}_{3}-\mathrm{N}$ and DP were determined by ion chromatography [36].

Gutters in plots were sealed with a bentonite/soil mixture and were washed of free soil and clay before the rainfall simulations were initiated. Percent ground cover was measured by the line-transect method ( 3 transects and 10 observations per transect in each plot), and mean volumetric soil moisture 
TABLE 2: Plant available nitrogen (PAN) and total phosphorus (TP) included in mineral fertilizer and biosolids treatments.

\begin{tabular}{lccc}
\hline Constituent & $\mathrm{LB}^{\dagger}$ & $\begin{array}{c}\mathrm{HB} \\
\mathrm{Kg} \mathrm{ha}^{-1}\end{array}$ & $\mathrm{MF}$ \\
\hline PAN $^{\ddagger}$ & 36.8 & 73.6 & 89.3 \\
$\mathrm{TP}$ & 58.3 & 116.6 & 146.9 \\
\hline
\end{tabular}

${ }^{\dagger}$ LB: low rate of biosolids; HB: high rate of biosolids; MF: mineral fertilizer.

${ }^{\ddagger}$ For MF, PAN is equal to ammoniacal nitrogen $\left(\mathrm{NH}_{4}-\mathrm{N}\right)$ content.

$(\theta)$ was determined (Table 1$)$ using a capacitance sensor (Theta probe, Delta-T Devices (brand name is included for specificity, not as an official endorsement of a particular product), Cambridge, UK) at four locations within a plot. Biosolids or MF were then spread manually to each plot with careful attention to uniformity and the treatment assigned.

2.2. Biosolids Experiment Details. The four treatments included untreated control (C); $1664 \mathrm{kgha}^{-1}$ low rate of biosolids with a $1 \mathrm{~m}$ vegetative filter (LBF); $1664 \mathrm{~kg} \mathrm{ha}^{-1}$ low rate of biosolids, unfiltered (LBU); $3328 \mathrm{~kg} \mathrm{ha}^{-1}$ high rate of biosolids with a $1 \mathrm{~m}$ vegetative filter (HBF). PAN and TP values for these treatments are given in Table 2. Filtered treatments received a uniform application of biosolids only on the upslope half of the plot (upper $1 \mathrm{~m}$ section) with the downslope half of the plot (lower $1 \mathrm{~m}$ section) acting as an untreated VFS. Biosolids were only spread on the downslope half of the unfiltered treatments (lower $1 \mathrm{~m}$ section) (i.e., no VFS). Therefore, the LBF and LBU treatments had the same plot size, treated area, and mass of biosolids applied.

The anaerobically digested, dewatered municipal biosolids used in this study were Class B biosolids [37] and were obtained from the Southwest Water Treatment Plant in Springfield, Missouri. Application rates for biosolids treatments were based on the plant available nitrogen (PAN) content of the biosolids, which was calculated by multiplying the organic $\mathrm{N}$ fraction of the biosolids (i.e., $\mathrm{TKN}-\left(\mathrm{NH}_{4}-\mathrm{N}+\right.$ $\mathrm{NO}_{3}-\mathrm{N}$ )) by the first year-mineralization rates (i.e., 0.2) [21] and then adding $0.7 * \mathrm{NH}_{4}-\mathrm{N}$ (to adjust for volatilization losses) [22] and $\mathrm{NO}_{3}-\mathrm{N}$ (Table 2).

2.3. Mineral Fertilizer Experiment Details. A blend of triple superphosphate and diammonium phosphate served as the $\mathrm{MF}$ in the second experiment. Plots received no amendment (untreated control; C), $89.3 \mathrm{~kg}$ ammoniacal nitrogen $\left(\mathrm{NH}_{4}\right.$ N) ha ${ }^{-1}$ and $146.9 \mathrm{~kg} \mathrm{Pha}^{-1}$ as a blend of MF applied to upslope half $(1 \mathrm{~m})$ of the plot which was "filtered" by the downslope $1 \mathrm{~m}$ of the plot which served as a vegetative filter strip (MFF), or an identical rate of blended mineral fertilizer spread over the whole plot (MFW). Therefore, the plots were equal in total area, but the MFW treatment received twice as much fertilizer on a plot area basis. With this design we intended for the MFF treatment to simulate grassland bordered by a narrow span of vegetation that could serve as a buffer to a protected water body, slope change, or area of concentrated flow, whereas the MFW treatment would
TABLE 3: Concentration and total fecal coliform colony-forming units (CFUs) in runoff.

\begin{tabular}{lcc}
\hline Treatment $^{\dagger}$ & Mean CFUs in $100 \mathrm{~mL}$ & Mean total CFUs $^{\ddagger}$ \\
\hline LBU & 35,720 & $10,965,563$ \\
LBF & 7,080 & $1,348,587$ \\
HBF & 4,880 & 367,700 \\
C & 117 & 90,130 \\
\hline
\end{tabular}

${ }^{\dagger}$ LBU: low rate of biosolids, unfiltered; LBF: low rate of biosolids, filtered by a $1 \mathrm{~m}$ grass strip; HBF: high rate of biosolids, filtered by a $1 \mathrm{~m}$ grass strip; C: untreated control.

${ }^{\ddagger}$ Mean CFUs are given, but no differences among treatments were detected using preplanned orthogonal contrasts on raw, square-root, or $\log _{10}$ transformed data.

represent a landscape that received uniform fertilization up to the edge of an unprotected (no VFS) critical area.

2.4. Statistical Analyses. Because structured treatment levels (i.e., high rate of biosolids treatment was double that of low rate of biosolids treatment) violate an assumption of analysis of variance (ANOVA), the $\mathrm{C}$ and biosolids treatment effects from the biosolids experiment were assessed by curvefitting [38] and orthogonal contrasts (1 df) with the REG and GLM procedures [39]. For the mineral fertilizer experiment, ANOVA was performed on square-root transformed data which were then subjected to protected least significant difference (LSD) tests $(\alpha=0.05)$ and preplanned orthogonal contrasts as a randomized complete block design for the $\mathrm{C}$, MFF, and MFW treatments.

\section{Results and Discussion}

3.1. Biosolids Experiment. Mean fecal coliform CFUs concentrations ranged from about 100 (C) to nearly 36,000 (LBU) CFUs per $100 \mathrm{~mL}$ (Table 3). Plotting the data (Figure 1) helped us to visualize the poor relationship $\left(r^{2}=0.44\right)$ in runoff CFUs levels among filtered biosolids treatments. Still, it is important to observe that filtered treatments (LBF and HBF) had approximately one-fifth the CFU concentration observed in LBU runoff (Figure 1). Treatment means ( \pm s.d.) for CFUs per $100 \mathrm{~mL}$ for C, LBF, HBF, and LBU were $116 \pm$ $159,7080 \pm 11,195,4880 \pm 8159$, and $35,720 \pm 61731$, respectively. Large variability in bacterial concentration has been reported by others $[23,30,40]$ and feral animal or accidental introductions of fecal material to the plot areas may have contributed to variability; however, the contributions of such introductions would logically be small relative to contributions from biosolids treatments. The relatively low fecal coliform counts observed in runoff from $\mathrm{C}$ plots support this perspective. In studies by Coyne et al. [23, 30], comparisons of various sizes of poultry litter amended plots with different VFS lengths did not meet water quality goals for control of fecal coliforms in primary contact water. In this study, CFUs per $100 \mathrm{~mL}$ from the biosolids treatments (Table 3) greatly exceeded the maximum amount allowed in Missouri for whole body contact recreation (max. of 206 CFUs/100 mL) [41]. High levels of CFUs were expected 
TABLE 4: Untransformed treatment means for all analyzed biosolids nutrients in runoff from Experiment 1 simulated rainfall plots. Note: values have been extrapolated to $\mathrm{kg} \mathrm{ha}^{-1}$ basis.

\begin{tabular}{|c|c|c|c|c|}
\hline \multirow{2}{*}{ Contaminant } & $\mathrm{C}$ & LBF & LBU & HBF \\
\hline & \multicolumn{4}{|c|}{$\mathrm{Kg} \mathrm{ha}^{-1}$} \\
\hline $\mathrm{TSS}^{\dagger}$ & 15.7 & 12.0 & 37.0 & 10.3 \\
\hline TKN & 1.10 & 0.67 & 3.33 & 9.00 \\
\hline DTKN & 0.33 & 0.77 & 1.67 & 8.67 \\
\hline $\mathrm{NH}_{4}-\mathrm{N}$ & 0.07 & 0.47 & 2.07 & 0.93 \\
\hline $\mathrm{DNH}_{4}-\mathrm{N}$ & 0.07 & 0.47 & 2.10 & 0.87 \\
\hline $\mathrm{NO}_{3}-\mathrm{N}$ & 0.03 & 0.02 & 0.07 & 0.03 \\
\hline $\mathrm{TP}$ & 0.10 & 0.13 & 0.33 & 0.23 \\
\hline DP & 0.07 & 0.10 & 0.23 & 0.13 \\
\hline
\end{tabular}

${ }^{\dagger}$ TSS: total suspended solids; TKN: total Kjeldahl nitrogen; DTKN: dissolved total Kjeldahl nitrogen; $\mathrm{NH}_{4}-\mathrm{N}$ : ammoniacal nitrogen; $\mathrm{DNH}_{4}-\mathrm{N}$ : dissolved ammoniacal nitrogen; $\mathrm{NO}_{3}-\mathrm{N}$ : nitrate nitrogen; TP: total phosphorus; $\mathrm{DP}$ : dissolved phosphorus.

because a narrow VFS was employed rather than the much wider buffer that is required for biosolids applications in Missouri [22]. Furthermore, bacteria introduced from biosolids into soils have been shown to decline rapidly and have a limited survival time $[13,42]$. Large variability in fecal CFU levels has limited our ability to identify differences among treatments in another similarly constructed experiment [40].

Preplanned orthogonal contrasts and linear regression were used to compare and isolate aspects of this study. No differences could be declared among biosolids treatments for TSS in runoff. This result could be expected if biosolids are relatively rainfast and have a relatively low impact on altering sediment runoff levels. However, Harris-Pierce et al. [24] showed that increasing sludge rate can increase sediment levels. TSS content in runoff was numerically highest from LBU and $\mathrm{C}$ treatments (Table 4), but the slope of the regression was not significant for the $\mathrm{C}, \mathrm{LBF}$, and $\mathrm{HBF}$ treatments $(P=0.14)$. Previous research, using much longer VFS, indicated reductions in TSS from surface runoff when VFS are employed $[23,29]$. Increasing biosolids rate showed a strong linear relationship for $\mathrm{DP}\left(r^{2}=1.00\right.$, slope $\left.P<0.001\right)$ in surface runoff (Figure 2 ). This result is logically supported because DP losses from control plots would only include residual $\mathrm{P}$, whereas losses from the biosolids treatments would be comprised of soil P and DP from the biosolids amendment. An orthogonal contrast of LBF versus LBU indicated that losses of TP $(P=0.013)$ and $\mathrm{DP}(P=$ 0.043 ) from LBF were half of the quantities lost from LBU. A strong linear relationship was observed for $\mathrm{NH}_{4}-\mathrm{N}\left(r^{2}=\right.$ 0.99 , slope $P=0.030)$ and $\mathrm{DNH}_{4}-\mathrm{N}\left(r^{2}=1.00\right.$, slope $P=$ $0.004)$ indicating increased losses as PAN rate was doubled (Figure 3). An LBF and LBU contrast indicated differences for $\mathrm{NH}_{4}-\mathrm{N}(P=0.005)$ and $\mathrm{DNH}_{4}-\mathrm{N}(P=0.005)$, showing the efficacy of the VFS in reducing nutrient losses. TKN and DTKN data are not well described by linear regression; therefore orthogonal contrasts were used to compare the $\mathrm{C}$ to LBF and C to HBF. No differences were detected.

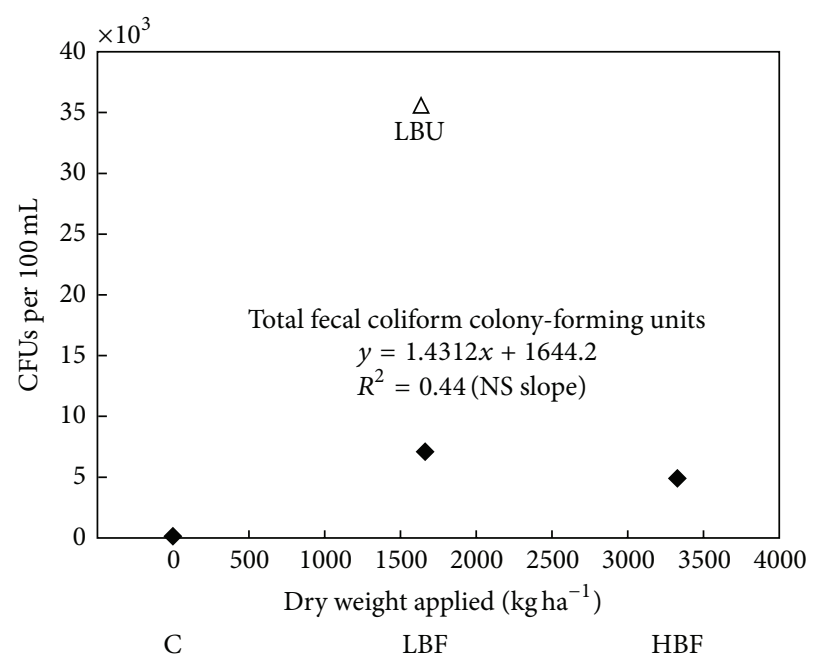

FIgURE 1: Mean fecal coliform colony-forming units (CFUs) concentrations in runoff from control (C); low rate of biosolids, filtered by a $1 \mathrm{~m}$ grass strip (LBF); low rate of biosolids, unfiltered (LBU); and high rate of biosolids, filtered by a $1 \mathrm{~m}$ grass strip (HBF). CFU level in runoff was not well described by application rate (slope $P=0.53$ ); however, mean CFU level of the unfiltered treatment was much greater. LBU mean is included for reference.

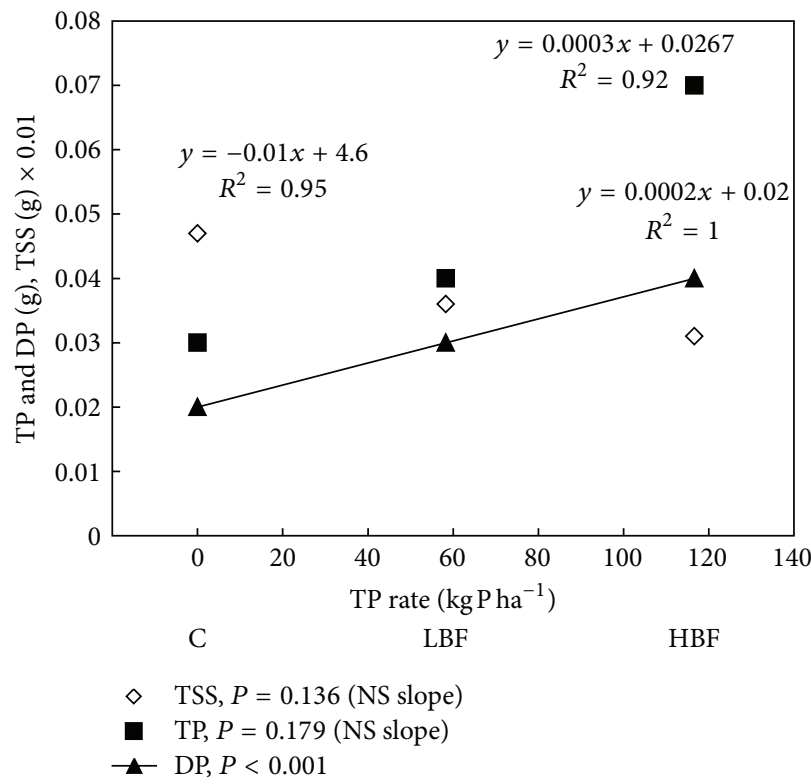

FIGURE 2: Total suspended solids (TSS), total phosphorus (TP), and dissolved phosphorus (DP) loading in response to TP application rate for $\mathrm{C}, \mathrm{LBF}$, and $\mathrm{HBF}$.

3.2. Mineral Fertilizer Experiment. In a separate analysis, $\mathrm{C}$ was compared to total nutrient runoff from the MF treatments. MFF loading did not differ from MFW for any factor according to the protected LSD mean separation procedure ( $\alpha=0.05$ ). However, according to an orthogonal contrast (1df), TP was marginally significant $(P=0.058)$ with MFW having nearly triple the amount of MFF TP loading (18.9 


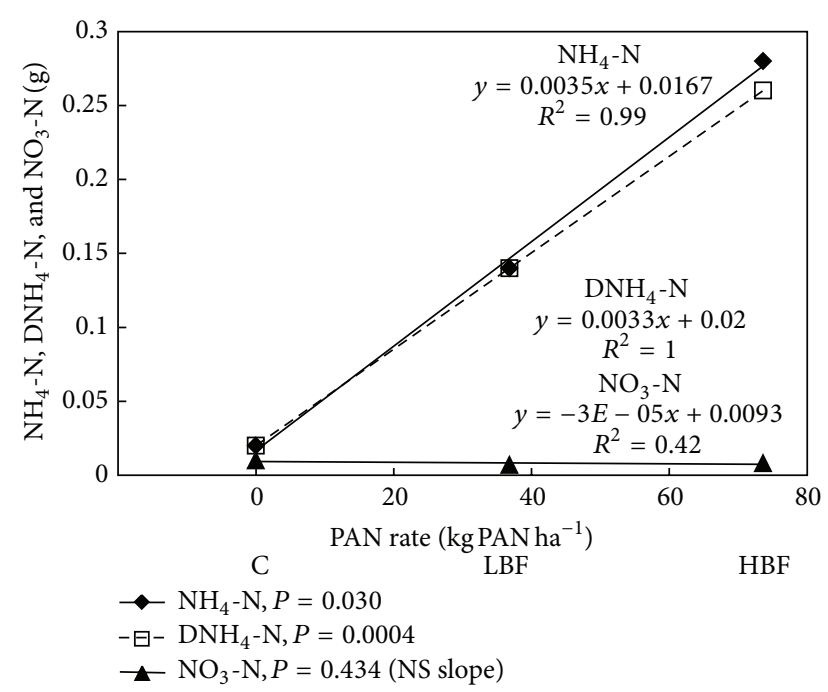

FIgURE 3: Total ammoniacal nitrogen $\left(\mathrm{NH}_{4}-\mathrm{N}\right)$, dissolved ammoniacal nitrogen $\left(\mathrm{DNH}_{4}-\mathrm{N}\right)$, and nitrate nitrogen $\left(\mathrm{NO}_{3}-\mathrm{N}\right)$ loading in response to plant available nitrogen $(\mathrm{PAN})$ application rate for $\mathrm{C}$, $\mathrm{LBF}$, and $\mathrm{HBF}$.

TABLE 5: Untransformed treatment means for all analyzed mineral fertilizer nutrients in runoff from Experiment 2 simulated rainfall plots. Note: values have been extrapolated to $\mathrm{a} \mathrm{kg} \mathrm{ha}^{-1}$ basis.

\begin{tabular}{lccc}
\hline Contaminant & $\mathrm{C}^{\dagger}$ & $\begin{array}{c}\text { MFF } \\
\mathrm{Kg} \mathrm{ha}^{-1}\end{array}$ & MFW \\
\hline TSS & $15.6^{\mathrm{a} \ddagger}$ & $17.6^{\mathrm{a}}$ & $5.7^{\mathrm{a}}$ \\
$\mathrm{TKN}$ & $1.1^{\mathrm{b}}$ & $5.9^{\mathrm{ab}}$ & $16.7^{\mathrm{a}}$ \\
$\mathrm{DTKN}$ & $0.33^{\mathrm{b}}$ & $5.4^{\mathrm{ab}}$ & $16.4^{\mathrm{a}}$ \\
$\mathrm{NH}_{4}-\mathrm{N}$ & $0.067^{\mathrm{b}}$ & $5.4^{\mathrm{ab}}$ & $15.7^{\mathrm{a}}$ \\
$\mathrm{DNH}_{4}-\mathrm{N}$ & $0.067^{\mathrm{b}}$ & $5.4^{\mathrm{ab}}$ & $15.6^{\mathrm{a}}$ \\
$\mathrm{NO}_{3}-\mathrm{N}$ & $0.033^{\mathrm{b}}$ & $0.2^{\mathrm{ab}}$ & $0.4^{\mathrm{a}}$ \\
$\mathrm{TP}^{\S}$ & $0.10^{\mathrm{b}}$ & $5.4^{\mathrm{ab}}$ & $18.9^{\mathrm{a}}$ \\
$\mathrm{DP}^{\S}$ & $0.07^{\mathrm{a}}$ & $1.5^{\mathrm{a}}$ & $13.9^{\mathrm{a}}$ \\
\hline
\end{tabular}

${ }^{\dagger} \mathrm{C}$ : untreated control; MFF: fertilizer, filtered by a $1.0 \mathrm{~m}$ grass strip; MFW: fertilizer applied to whole plot.

${ }^{\ddagger}$ Values within a row followed by different letters are significantly different according to a protected LSD test $(\alpha=0.05)$.

${ }^{\S}$ Three DP samples were lost due to a laboratory error. The consequent loss of statistical power may have contributed to a failed $F$-test $(P=0.147)$ for the protected LSD procedure.

versus $5.4 \mathrm{~kg} \mathrm{ha}^{-1}$ ) (Table 5). MFW runoff content of $\mathrm{NH}_{4}$ $\mathrm{N}$ numerically (but not statistically) exceeded that of the MFF plot by a factor of nearly three also. A higher level of nutrient runoff in the MFW plot was, of course, expected because double the amount of fertilizer was applied to the same total plot area and the closer proximity of half of the fertilizer to the collection gutter. However, the narrow VFS of mixed cool-season grasses employed in this experiment were inadequate to significantly reduce nutritive loading. The high water solubility of MF allows a large amount of contaminants to be readily carried off in surface runoff when a sufficient rainfall storm occurs; therefore, wider VFS (e.g., $9.1 \mathrm{~m}$ to $45.7 \mathrm{~m}$ ) are recommended to reduce losses to surface waters. No differences were observed for TSS among the C and fertilizer treatments according to the protected LSD test $(\alpha=0.05)$ (Table 5). According to the same test, TKN, DTKN, $\mathrm{NH}_{4}-\mathrm{N}, \mathrm{DNH}_{4}-\mathrm{N}, \mathrm{NO}_{3}-\mathrm{N}$, and $\mathrm{TP}$ were lower in runoff from the $\mathrm{C}$ than MFW.

These results suggest that even an undersized VFS can reduce certain nutrients when compared to fertilizer applications made without any VFS. DTKN and $\mathrm{DNH}_{4}-\mathrm{N}$ were dominant components of TKN and total $\mathrm{NH}_{4}-\mathrm{N}$ values in runoff among all treatments. This result was expected from soluble mineral fertilizer salts and resulted in nearly identical trends among these parameters.

\section{Conclusions}

Statistical analysis of fecal coliform in runoff was obscured by variability and perhaps made worse by historical or accidental contamination of plots. However, that the biosolids treatment LBU numerically had the highest mean concentration and total runoff of coliform is noteworthy. In the LBF versus LBU contrast, differences suggest that even a small VFS is capable of decreasing biosolids nutrient levels in runoff when compared to unfiltered runoff. Biosolids applications in the state of Missouri, however, require much wider buffer areas (15.2 to $91.4 \mathrm{~m}$ ) than those used in these experiments [22].

MFF and MFW did not differ in any of the orthogonal contrasts. However, it is important to notice that, except for TSS, MFW always differed from the $\mathrm{C}$ according to a protected LSD test $(\alpha=0.05)$, while MFF did not differ from the C. Although VFS are recommended when applying mineral fertilizers, they are not required in Missouri. These data indicate that lack of VFS where mineral fertilizers are applied could result in large nutrient content being delivered to surface water.

\section{Abbreviations}

$\begin{array}{ll}\text { MF: } & \text { Mineral fertilizer } \\ \text { CFUs: } & \text { Colony-forming units } \\ \mathrm{DNH}_{4}-\mathrm{N}: & \text { Dissolved ammoniacal nitrogen } \\ \mathrm{DP}: & \text { Dissolved phosphorus } \\ \mathrm{DTKN}: & \text { Dissolved total Kjeldahl nitrogen } \\ \mathrm{NH}_{4}-\mathrm{N}: & \text { Ammoniacal nitrogen (total) } \\ \mathrm{NO}_{3}-\mathrm{N}: & \text { Nitrate nitrogen } \\ \mathrm{PAN} & \text { Plant available nitrogen } \\ \mathrm{TKN}: & \text { Total Kjeldahl nitrogen } \\ \mathrm{TP}: & \text { Total phosphorus } \\ \text { TSS: } & \text { Total suspended solids. }\end{array}$

\section{Conflict of Interests}

The authors declare that there is no conflict of interests regarding the publication of this paper.

\section{References}

[1] Missouri Department of Natural Resources, Missouri continuing planning process, Element 7MODNR, Jefferson City, MO, USA, 2001, http://www.dnr.mo.gov/env/wpp/cpp/SecIIE7.pdf. 
[2] S. I. Torri, R. Corrêa, G. Renella, A. Valdecantos, and L. Perelomov, "Biosolids soil application: why a new special on an old issue?" Applied and Environmental Soil Science, vol. 2012, Article ID 265783, 3 pages, 2012.

[3] Q. Lu, Z. L. He, and P. J. Stoffella, "Land application of biosolids in the USA: a review," Applied and Environmental Soil Science, vol. 2012, Article ID 201462, 11 pages, 2012.

[4] M. Antiĺn, M. Briceño, G. Galindo, and M. Escudey, "Effect of biosolids on the organic matter content and phosphorus chemical fractionation of heated volcanic Chilean soils," Australian Journal of Soil Research, vol. 46, no. 5, pp. 415-422, 2008.

[5] V. Samaras, C. D. Tsadilas, and S. Stamatiadis, "Effects of repeated application of municipal sewage sludge on soil fertility, cotton yield, and nitrate leaching," Agronomy Journal, vol. 100, no. 3, pp. 477-483, 2008.

[6] R. E. Zartman, C. A. Moffet, D. B. Wester, R. E. Sosebee, E. B. Fish, and W. F. Jaynes, "Influence of surface biosolids application on infiltration.," Applied and Environmental Soil Science, vol. 2012, Article ID 642791, 9 pages, 2012.

[7] C. D. Tsadilas, I. K. Mitsios, and E. Golia, "Influence of biosolids application on some soil physical properties," Communications in Soil Science and Plant Analysis, vol. 36, no. 4-6, pp. 709-716, 2005.

[8] B. M. Wallace, M. Krzic, T. A. Forge, K. Broersma, and R. F. Newman, "Biosolids increase soil aggregation and protection of soil carbon five years after application on a crested wheatgrass pasture," Journal of Environmental Quality, vol. 38, no. 1, pp. 291298, 2009.

[9] C. G. Cogger, A. I. Bary, S. C. Fransen, and D. M. Sullivan, "Seven years of biosolids versus inorganic nitrogen applications to tall fescue," Journal of Environmental Quality, vol. 30, no. 6, pp. 2188-2194, 2001.

[10] D. L. Binder, A. Dobermann, D. H. Sander, and K. G. Cassman, "Biosolids as nitrogen source for irrigated maize and rainfed sorghum," Soil Science Society of America Journal, vol. 66, no. 2, pp. 531-543, 2002.

[11] G. Pu, M. Bell, G. Barry, and P. Want, "Fate of applied biosolids nitrogen in a cut and remove forage system on an alluvial clay loam soil," Australian Journal of Soil Research, vol. 46, no. 8, pp. 703-709, 2008.

[12] H. J. Lagae, M. Langemeier, D. Lybecker, and K. Barbarick, "Economic value of biosolids in a semiarid agroecosystem," Agronomy Journal, vol. 101, no. 4, pp. 933-939, 2009.

[13] E. P. Dunigan and R. P. Dick, "Nutrient and coliform losses in runoff from fertilized and sewage sludge-treated soil," Journal of Environmental Quality, vol. 9, no. 2, pp. 243-250, 1980.

[14] R. V. McLeod and R. O. Hegg, "Pasture runoff water quality from application of inorganic and organic nitrogen sources," Journal of Environmental Quality, vol. 13, no. 1, pp. 122-126, 1984.

[15] D. R. Edwards and T. C. Daniel, "Effects of poultry litter application rate and rainfall intensity on quality of runoff from fescuegrass plots," Journal of Environmental Quality, vol. 22, no. 2, pp. 361-365, 1993.

[16] G. J. Gascho, R. D. Wauchope, J. G. Davis et al., "Nitratenitrogen, soluble, and bioavailable phosphorus runoff from simulated rainfall after fertilizer application," Soil Science Society of America Journal, vol. 62, no. 6, pp. 1711-1718, 1998.

[17] B. Eghball and J. E. Gilley, "Phosphorus and nitrogen in runoff following beef cattle manure or compost application," Journal of Environmental Quality, vol. 28, no. 4, pp. 1201-1210, 1999.
[18] T. J. Sauer, T. C. Daniel, P. A. Moore Jr., K. P. Coffey, D. J. Nichols, and C. P. West, "Poultry litter and grazing animal waste effects on runoff water quality," Journal of Environmental Quality, vol. 28, no. 3, pp. 860-865, 1999.

[19] D. H. Pote, W. L. Kingery, G. E. Aiken, F. X. Han, P. A. Moore Jr., and K. Buddington, "Water-quality effects of incorporating poultry litter into perennial grassland soils," Journal of Environmental Quality, vol. 32, no. 6, pp. 2392-2398, 2003.

[20] A. L. Shober and J. T. Sims, "Phosphorus restrictions for land application of biosolids: current status and future trends," Journal of Environmental Quality, vol. 32, no. 6, pp. 1955-1964, 2003.

[21] USEPA, "Land application of sewage sludge: a guide for land appliers on the requirements of the federal standards for the use or disposal of sewage sludge, 40 CFR Part 503," in USEPA Office of Enforcement and Compliance Assurance, Washington, DC, USA, 1994.

[22] K. Arnold, J. H. Dunn, and J. D. Carpenter, "Best management practices for biosolids land application," University of Missouri Extension, Columbia, MO, USA, 1994, http://extension.missouri.edu/publications/DisplayPub.aspx?P=WQ426.

[23] M. S. Coyne, R. A. Gilfillen, R. W. Rhodes, and R. L. Blevins, "Soil and fecal coliform trapping by grass filter strips during simulated rain," Journal of Soil and Water Conservation, vol. 50, no. 4, pp. 405-408, 1995.

[24] R. L. Harris-Pierce, E. F. Redente, and K. A. Barbarick, "Sewage sludge application effects on runoff water quality in a semiarid grassland," Journal of Environmental Quality, vol. 24, no. 1, pp. 112-115, 1995.

[25] R. B. Daniels and J. W. Gilliam, "Sediment and chemical load reduction by grass and riparian filters," Soil Science Society of America Journal, vol. 60, no. 1, pp. 246-251, 1996.

[26] X. Liu, X. Zhang, and M. Zhang, "Major factors influencing the efficacy of vegetated buffers on sediment trapping: a review and analysis," Journal of Environmental Quality, vol. 37, no. 5, pp. 1667-1674, 2008.

[27] J. J. Fajardo, J. W. Bauder, and S. D. Cash, "Managing nitrate and bacteria in runoff from livestock confinement areas with vegetative filter strips," Journal of Soil and Water Conservation, vol. 56, no. 3, pp. 185-191, 2001.

[28] M. Abu-Zreig, R. P. Rudra, H. R. Whiteley, M. N. Lalonde, and N. K. Kaushik, "Phosphorus removal in vegetated filter strips," Journal of Environmental Quality, vol. 32, no. 2, pp. 613-619, 2003.

[29] H. Blanco-Canqui, C. J. Gantzer, S. H. Anderson, E. E. Alberts, and A. L. Thompson, "Grass barrier and vegetative filter strip effectiveness in reducing runoff, sediment, nitrogen, and phosphorus loss," Soil Science Society of America Journal, vol. 68, no. 5, pp. 1670-1678, 2004.

[30] M. S. Coyne, R. A. Gilfillen, A. Villalba et al., "Fecal bacteria trapping by grass filter strips during simulated rain," Journal of Soil and Water Conservation, vol. 53, no. 2, pp. 140-145, 1998.

[31] A. K. Guber, A. M. Yakirevich, A. M. Sadeghi, Y. A. Pachepsky, and D. R. Shelton, "Uncertainty evaluation of coliform bacteria removal from vegetated filter strip under overland flow condition," Journal of Environmental Quality, vol. 38, no. 4, pp. 1636$1644,2009$.

[32] J. B. Humphry, T. C. Daniel, D. R. Edwards, and A. N. Sharpley, "A portable rainfall simulator for plot-scale runoff studies," Applied Engineering in Agriculture, vol. 18, no. 2, pp. 199-204, 2002. 
[33] APHA, Standard Methods for the Examination of Water and wasteWater, APHA, Washington, DC, USA, 21st edition, 1999.

[34] USEPA, Method 351.2. Determination of total Kjeldahl nitrogen by semi-automated colorimetry, USEPA, Washington, DC, 1993, http://water.epa.gov/scitech/methods/cwa/bioindicators/ upload/2007_07_10_methods_method_351_2.pdf.

[35] USEPA, Method 365.4. Phosphorus, total (colorimetric, automated, block digester AA II). USEPA, Washington, DC, USA, 1974, http://water.epa.gov/scitech/methods/cwa/bioindicators/upload/2007_07_10_methods_method_365_4.pdf.

[36] USEPA, "Method 300.0. Determination of inorganic anions by ion chromatography," USEPA, Washington, DC, USA, 1993, http://water.epa.gov/scitech/methods/cwa/bioindicators/ upload/2007_07_10_methods_method_300_0.pdf.

[37] R. Miles and J. R. Brown, Biosolids glossary of terms. University of Missouri Extension Bulletin WQ449, 1995, http:// extension.missouri.edu/p/WQ449.

[38] R. Cousens, "Misinterpretations of results in weed research through inappropriate use of statistics," Weed Research, vol. 28, pp. 281-289, 1988.

[39] SAS, SAS/STAT 9.2 User'S Guide, SAS Institute, Cary, NC, USA, 2008.

[40] C. B. Wallace, M. G. Burton, S. G. Hefner, and T. A. DeWitt, "Effect of preceding rainfall on sediment, nutrients, and bacteria in runoff from biosolids and mineral fertilizer applied to a hayfield in a mountainous region," Agricultural Water Management, vol. 130, pp. 113-118, 2013.

[41] Missouri Department of Natural Resources, Rules of Department of Natural Resources. Division 20. Clean Water Commission. Chapter 7. Water QualityMODNR, Jefferson City, Mo, USA, 2010, http://www.sos.mo.gov/adrules/csr/current/ 10csr/10c20-7a.pdf.

[42] N. L. Lang, M. D. Bellett-Travers, and S. R. Smith, "Field investigations on the survival of Escherichia coli and presence of other enteric micro-organisms in biosolids-amended agricultural soil," Journal of Applied Microbiology, vol. 103, no. 5, pp. 1868-1882, 2007. 

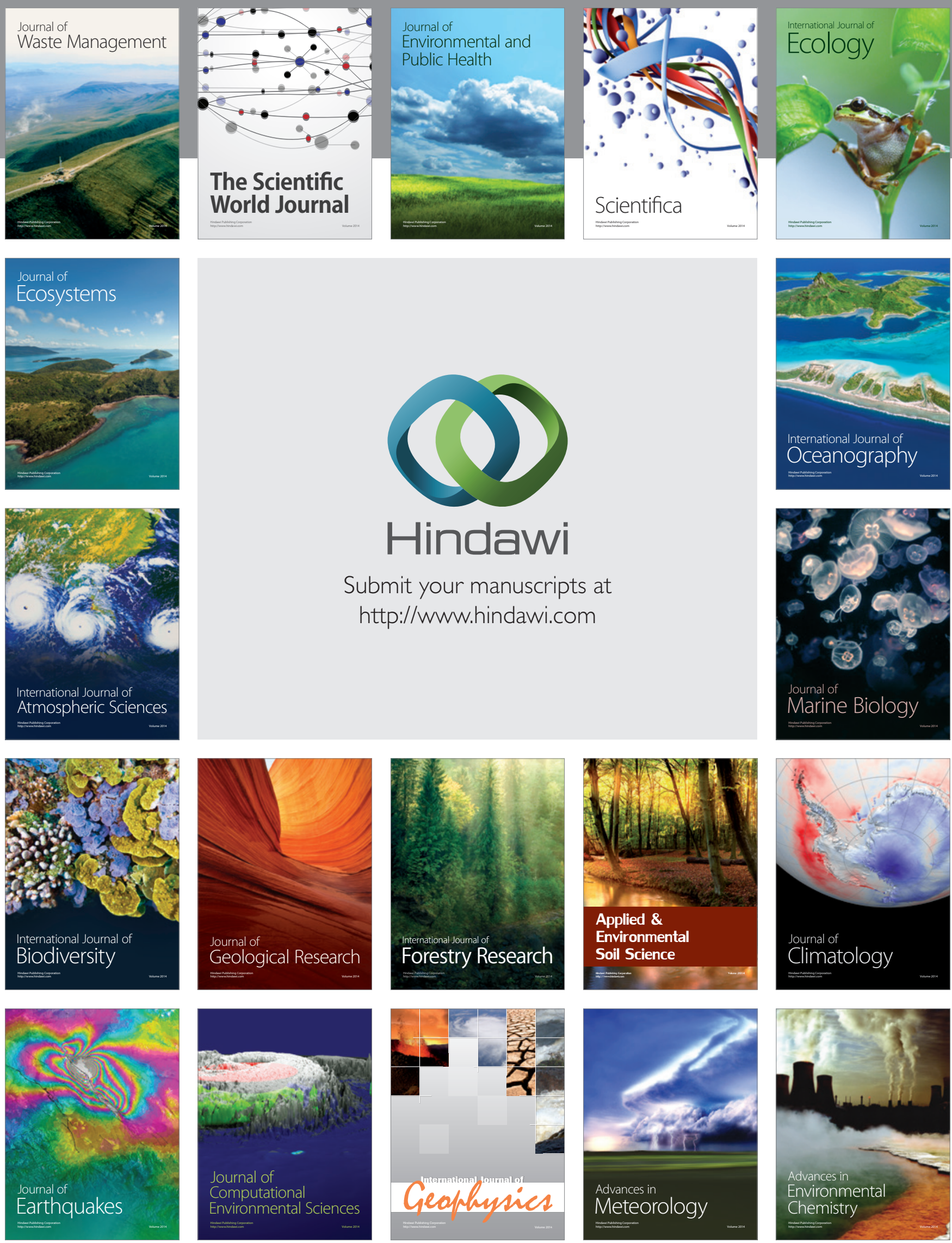